\section{$\underset{\substack{\text { hommes } \\ \text { \& migrations }}}{ }$}

\section{Hommes \& migrations}

Revue française de référence sur les dynamiques

migratoires

1289 | 2011

Les frontières du sport

\title{
Dernier étage, gauche, gauche
}

Film français de Angelo Cianci

\section{André Videau}

\section{(2) OpenEdition \\ 1 Journals}

\section{Édition électronique}

URL : http://journals.openedition.org/hommesmigrations/822

DOI : $10.4000 /$ hommesmigrations.822

ISSN : 2262-3353

\section{Éditeur}

Musée national de l'histoire de l'immigration

\section{Édition imprimée}

Date de publication : 1 janvier 2011

Pagination : 148

ISSN : 1142-852X

\section{Référence électronique}

André Videau, «Dernier étage, gauche, gauche», Hommes \& migrations [En ligne], 1289 | 2011, mis en ligne le 29 mai 2013, consulté le 22 septembre 2020. URL : http://journals.openedition.org/ hommesmigrations/822 ; DOI : https://doi.org/10.4000/hommesmigrations.822

Ce document a été généré automatiquement le 22 septembre 2020.

Tous droits réservés 


\title{
Dernier étage, gauche, gauche
}

\author{
Film français de Angelo Cianci
}

\section{André Videau}

1 En ce jour anniversaire du 11 septembre, rien ne prédisposait à l'esclandre la famille Atel-Hadj, père et fils (Mohamed Fellag et Aymen Saïdi) logés sans histoire au $7^{\mathrm{e}}$ gauche, gauche, dans un bloc de la cité. C'était compter sans la visite importune, au petit matin, de M. François Etcheverria, huissier de justice (Hippolyte Girardot), venant procéder à une saisie pour factures impayées. Le ton monte, les insultes volent, rendant toute explication inaudible, empêchant toute conciliation. Un huis clos à haute tension s'installe entre les trois hommes et, pour rester dans l'air du temps, les conditions semblent réunies pour une prise d'otages ou une attaque terroriste. Les autorités se mobilisent, les badauds s'émeuvent.

2 Le film rebondit entre comédie et dramaturgie explosives et échappe à toute classification dans laquelle on serait tenté de l'enfermer. Proche, mais sans collusion, de la comédie sociale à l'italienne ou de l'humour noir et corrosif du réalisme anglais à la Ken Loach, plus éloigné d'un docu-fiction engagé en banlieue à la manière de Richet ou de Kassovitz ou des polars de genre politico-mafieux avec règlement de comptes et prise d'otages. En réalité, le film, ni minimaliste, ni spectaculaire, est une fable complexe et profondément originale.

3 Sous une forme classique, l'intrigue feint de respecter les trois unités: le lieu sans quitter le modeste appartement HLM, le temps : 24 heures chrono entre l'escarmouche et l'issue, l'action en déclinant diverses postures de l'incommunicabilité. Mais, coincées entre drame et comédie, ces règles trop strictes sont faites pour être transgressées. Des comparses font intrusion: policiers, politiques, préfet, négociateurs, badauds (personnages inefficaces, mais habiles comédiens : Michel Vuillermoz, Lyes Salem...). Le langage repousse ses limites et devient un sabir qui emprunte au verlan, au louchebem, au manouche, au narvalo... Une expression libertaire qui nécessite presque un lexique. Quand le passé trouble et enfoui du père kabyle resurgit comme une boîte noire, un revolver chargé à blanc, on sera proche du dénouement, presque métaphysique. “ Personne n'a le privilège de la violence et de la bêtise... Il ne faut pas se lâcher." On tient le bon bout. 
4 Il reste à dire combien ce film est redevable au trio magistral d'interprètes. Avec une mention spéciale pour le jeune Aymen Saïdi. Il éructe avec une attendrissante fureur tous les griefs et les malentendus d'une génération. Remarqué dans Saint-Jacques... La Mecque de Coline Serreau, tout en partageant pendant des mois avec Myriam Boyer le succès théâtral de La vie devant soi, adaptation du roman de Romain Gary/Émile Ajar, il se taille avec brio une place enviée dans la toute nouvelle génération des "beurs" comédiens. 